\title{
Development of Bacillus subtilis Mutants for Overproduction of Protease
}

\author{
Mohsin I*, Muhammad A and Fareeha B
}

Department of Biochemistry, University of Agriculture, Pakistan

\begin{abstract}
Proteases are widely used in leather processing, silk industry, diary meat processing, and preparation of organic fertilizer as well as for the liberation of silver from recycled X-ray films. Ultraviolet radiation mutagenesis of Bacillus subtilis IBL-04 was carried out for hyper producing strain development. Mutants of Bacillus subtilis were isolated and screened for selection of hyper producing mutant. Production of protease by the selected mutant BS-90 (treated for $90 \mathrm{~min}$ ) was optimized by varying $\mathrm{pH}$, temperature, and inoculum size and fermentation time simultaneously in Response Surface Method (RSM) under Central Composite Design (CCD). The mathematical response model is considered to be reliable with an $R^{2}$ value of 0.9842 . The adjusted $R^{2}$ value was 0.9695 suggesting a significant model by determining the close relationship to the actual $R^{2}$ value. Predicted $R^{2}$ value shown in this model was 0.9133 . The "Pred R-Squared" of 0.9133 is close as to the "Adj R-Squared" of 0.9695 as expected. The ratio of 22.60 attained in this model represents an adequate signal. The calculated C.V was 3.25 which indicate the good level of model precision and reliability. The maximum enzyme activity was $95.89(\mathrm{IU} / \mathrm{mL})$ at optimum conditions $\mathrm{pH}$ 8, Temperature $50^{\circ} \mathrm{C}$, Inoculum size $2.5 \mathrm{~mL}$ and fermentation time $72 \mathrm{~h}$. These characteristics render its potential use in detergent industries for detergent formulation.
\end{abstract}

Keywords: Media optimization; Bacillus subtilis; UV mutagenesis; Alkaline detergent proteases; Low-cost media

\section{Introduction}

Proteolytic enzymes or proteases are the most important enzymes in industry, accounting for $60 \%$ of the total enzyme sales in the world [1]. They are used in the regulation of metabolism, gene expression, enzyme modification, pathogenicity and diverse processes in the different industries [2]. Microbial proteases play an important role in the production of traditional fermented foods, enzyme industries, dominated by microbial protease products. They also find use in food processing, detergents, therapeutic agents and organic chemical synthesis $[3,4]$. The demand and supply of proteases can be balanced by developing and exploring new microbial strain to increase their production. Alkaline proteases constitute $60-65 \%$ of the global industrial market. These proteases are the single class of enzymes widely used in detergents, pharmaceuticals, leather and the food and agriculture industries. Proteolytic enzymes support the natural healing process in local management of skin ulceration by efficient removal of necrotic material. Proteases catalyze or hydrolyze protein and therefore play a vital role in various industrial applications. Proteolytic enzymes catalyse in tumor invasion and also in infection cycle of pathogenic microorganisms. They are also involve in disease causing organisms which cause of developing therapeutic agents against fatal disease like cancer and AIDS [5]. For maximum yield, selected organisms are grown in fermenters under optimum conditions and can be further used to make products such as cheese, bread, wine and beer [6].

The production of an enzyme in Bacillus subtilis has a characteristic relationship with regard to the growth phase of the organism. Production of protease is controlled by specific genes that are induced and UV-treated in response to the growth substrates during transition state between exponential growth and the stationary phase. The rate of enzyme production is variable in specific microorganisms. But protease synthesis is correlated with the onset of a high rate of protein turnover $[7,8]$.

Mutation is one of the processes being used to enhance the production of enzymes. Mutations can be induced by the methods of random-mutagenesis or site-directed mutagenesis [9]. The possible alteration in proteins by the process of mutagenesis causes changes in the binding affinity, specificity, catalytic rate and thermo stability of enzymes. By random mutagenesis, new unanticipated mutations at random places are found which have critical importance for the function of protein of interest. However, in some cases random mutation process may lead to the silencing of a gene. While in site-directed mutagenesis, the positions of functional importance are defined in a protein that is a good tool, to understand the protein structure function relationship. The structure function relationships are determined by comparing the amino-acid sequence in native and mutant proteins. UV irradiation and Chemical mutation processes are commonly used. Effective, easy and low cost techniques used for the improvement of microbial strains for developing hyper producing microbial fermentation processes.

UV-B (280 to $320 \mathrm{~nm}$ ) and UV-C (100 to $280 \mathrm{~nm}$ ) cause both indirect and direct damage because of the strong absorption at wavelengths below $320 \mathrm{~nm}$ by the DNA molecule. The most abundant products formed by irradiation with UV-B are cyclobutane pyrimidine dimers. (CPD) (22). The pyrimidine dimers at specific region of Bacillus subtilis DNA may treat in recovery of protease genes that alters enzyme production [10].

Bacteria have several repair mechanisms in response to UVRinduced damage. These mechanisms are usually classified into dark repair (DR) and photoreactivation. There are three different dark repair mechanisms described here: (i) nucleotide excision repair, (ii) postreplication recombinational repair, and (iii) error-prone repair. All mechanisms are inducible as part of the SOS regulon and the induction is dependent on DNA damage [11].

The present study was conducted to improve bacterial strain through mutation and optimized the conditions such as $\mathrm{pH}$, temperature, size

*Corresponding author: Mohsin I, Department of Biochemistry, University of Agriculture, Pakistan, Tel: 9231367673676; E-mail: mohsiniqbal5050@gmail.com

Received June 12, 2017; Accepted July 13, 2017; Published July 20, 2017

Citation: Mohsin I, Muhammad A, Fareeha B (2017) Development of Bacillus subtilis Mutants for Overproduction of Protease. J Microb Biochem Technol 9:174180. doi: $10.4172 / 1948-5948.1000363$

Copyright: @ 2017 Mohsin I, et al. This is an open-access article distributed under the terms of the Creative Commons Attribution License, which permits unrestricted use, distribution, and reproduction in any medium, provided the original author and source are credited. 
of inoculum and fermentation time to enhance enzyme yield to make the process of production cost effective. Structure analysis as well as extensive biochemical and genetic studies of the proteasome and the ubiquitin system led to a basic model of substrate recognition and degradation by enzymes. The proteasome as the proteolytic machine degrading those cellular proteins in vivo that had been tagged with ubiquitin constituted the ignition spark, which led to the explosion of knowledge of a new regulatory principle of eukaryotic cells, now known as selective proteolysis via the ubiquitin-proteasome system (UPS). This system is unique in cellular regulation as in contrast to phosphorylation/dephosphorylation of a protein it allows a complete shutdown of function of a selected protein molecule due to its irreversible proteolysis [12].

\section{Materials and Methods}

\section{Place of work}

The experimental and analytical work was done in industrial biotechnology laboratory (IBL), department of biochemistry, University of Agriculture, Faisalabad. All chemicals used in this study were of analytical grade. These chemicals were purchased from SigmaUSA and Oxide, UK through local agents.

\section{Microorganism}

The bacterial strain Bacillus subtilis was obtained from Industrial Biotechnology lab (IBL), Department of Biochemistry, University of Agriculture, Faisalabad. Bacillus subtilis was grown on nutrient agar slants at $37^{\circ} \mathrm{C}$ for $24 \mathrm{~h}$ and then preserved at $4^{\circ} \mathrm{C}$ for one month [13].

\section{Inoculum preparation}

Luria-Bertania (LB) medium (1.55 g/L) was prepared in $250 \mathrm{~mL}$ Erlenmeyer flasks. The $\mathrm{pH}$ of the medium was adjusted to 7.5 using $\mathrm{NaOH} / \mathrm{HCL}$ and autoclaved at $\left(121^{\circ} \mathrm{C}\right)$ for $15 \mathrm{~min}$. A loop full Bacillus subtilis cells were transferred into the sterilized medium. The flasks were shaken (200 rpm) for $24 \mathrm{~h}$ to get a homogeneous cell suspension [14].

\section{UV mutagenesis of Bacillus subtilis}

To enhance the production of protease enzyme $24 \mathrm{~h}$ old culture was taken, centrifuge at 10,000 rpm and the cells were washed twice with phosphate buffer $(50 \mathrm{mM}, \mathrm{pH}$ 7.0).The pellet was suspended in $50 \mathrm{mM}$ phosphate buffer ( $\mathrm{pH}$ 7.0) and transfered into sterile Petri plates. One plate was kept in dark which served as control and the rest were exposed to UV radiation for different time intervals varying from 30-120 min with 30 min interval. UV detection lamp $365 \mathrm{~nm}$, Fisher Scientific Ltd., Pandan Crescent, UE Tech Park, Singapore was used. After UV irradiation they were kept in dark for stabilization of thymine-thymine dimers (T-T), followed by inoculation with $0.1 \mathrm{ml}$ of the UV treated bacterial suspensions on skim milk agar plates. These were incubated for $48 \mathrm{~h}$ at $37^{\circ} \mathrm{C}$ for colony formation. Triton X-100 (1$2 \%)$ was the colony restrictor used in the medium. It is a chemical used to restrict the growth of bacterial colonies appearing on the media. The colonies which showed more intense zones on skim milk agar plates were selected as mutants for production of protease [15].

\section{Liquid state fermentation for protease production}

Protease production was carried out by growing the selected mutants in $250 \mathrm{~mL}$ Erlenmeyer flasks containing $100 \mathrm{~mL}$ of medium. The medium contained the following $(\mathrm{g} / \mathrm{L})$ in distilled water: peptone, 1.0 ; maltose, $4.0 ; \mathrm{NaNO}_{3}, 0.5 ; \mathrm{KH}_{2} \mathrm{PO}_{4}, 0.5 ; \mathrm{MgSO}_{4} .7 \mathrm{H}_{2} \mathrm{O}, 0.02 ; \mathrm{Na}_{2} \mathrm{CO}_{3}$, 1.0. The medium was sterilized by autoclaving at $121^{\circ} \mathrm{C}$ for $15 \mathrm{~min}$. The medium was inoculated with Bacillus subtilis mutants and incubated at $35^{\circ} \mathrm{C}$ for $24 \mathrm{~h}$. After three days, the broth was centrifuge at $10,000 \mathrm{rpm}$ for $20 \mathrm{~min}$ at $4^{\circ} \mathrm{C}$ and the supernatant was used as extracellular enzyme extract [15].

\section{Analytical procedures}

Protease assay: Protease enzyme activity was measured by the addition of casein in phosphate buffer $(\mathrm{pH} 7)$ at $37^{\circ} \mathrm{C}$. The oxidation of casein was determined at $660 \mathrm{~nm}$ using a UV/Vis spectrophotometer. Enzyme activities were expressed in $\mathrm{U} / \mathrm{mL}$ [6].

\section{Formula:}

Units / $m L$ enzyme $=\frac{\mu \text { mol tyrosine equivalents released } \times \text { total volume of assay }}{A \times B \times C}$

$A=$ volume of enzyme used

$\mathrm{B}=$ Time required for assay $(20 \mathrm{~min})$

$\mathrm{C}=$ Volume used in colorimetric determination $(1 \mathrm{ml})$

\section{Optimization of different factors for hyper production of protease enzyme}

After protease production by different mutants, the best protease producer mutant BS-90 (treated for $90 \mathrm{~min}$ ) was selected. Various fermentation process parameters effecting enzyme production during liquid state fermentation (LSF) were optimized. The parameters optimized were: (1) Incubation temperature $\left(35-55^{\circ} \mathrm{C}\right)$; (2) initial $\mathrm{pH}$ (6.0-10.0), (3) incubation period (24-120h) and (4) inoculums size (1-4 $\mathrm{mL}$ ) varied simultaneously adopting Response Surface Methodology (RSM) strategy under Central Composite Design (CCD) using Design Expert software (Version 6.0) (Table 1).

Design expert (version 7.0) depends upon two things which are group of controlled experimental factors and measured responses.

There is a 4 factor design which was used to fit the second order polynomial model. It shows that 30 flask experiments were required for this procedure (Table 2). The optimum values were taken by solving the regression equation. The 30 flasks fermentation experiment was performed as triplicate [16]. The medium with different $\mathrm{pH}$ was added in $250 \mathrm{ml}$ Erlenmeyer flasks. The contents of the flask were autoclaved at $121^{\circ} \mathrm{C}$. Substrate was inoculated with varying Bacillus subtilis inoculum size in each flask. The contents of the flask were mixed thoroughly and incubated at different temperatures for different fermentation time periods.

\section{Results and Discussion}

In the present study, the UV irradiation mutagenesis was carried out to develop a high protease yielding mutant of Bacillus subtilis IBL04. After the selection of hyper-producing mutant strain, the physical parameters (inoculum size, incubation time, $\mathrm{pH}$ and temperature) were optimized by RSM (Response Surface Methodology) under CCD (Central Composite Design) to improve the production of protease. Later on, the enzyme was purified and characterized. The results

\begin{tabular}{|c|c|c|}
\hline Independent Variables & \multicolumn{2}{|c|}{ Coded levels } \\
\hline Ranges & $\mathbf{- 1}$ & $\mathbf{+ 1}$ \\
\hline $\mathrm{pH}$ & 6 & 10 \\
\hline Temperature $\left({ }^{\circ} \mathrm{C}\right)$ & 35 & 55 \\
\hline Inoculum Size $(\mathrm{mL})$ & 1 & 4 \\
\hline Fermentation Time $(\mathrm{h})$ & 24 & 120 \\
\hline
\end{tabular}

Table 1: Ranges of independent experimental variables. 
Citation: Mohsin I, Muhammad A, Fareeha B (2017) Development of Bacillus subtilis Mutants for Overproduction of Protease. J Microb Biochem Technol 9:174-180. doi: 10.4172/1948-5948.1000363

\begin{tabular}{|c|c|c|c|c|}
\hline Run & $\mathbf{p H}$ & Temperature $\left({ }^{\circ} \mathbf{C}\right)$ & $\begin{array}{c}\text { Inoculum Size } \\
(\mathbf{m L})\end{array}$ & $\begin{array}{c}\text { Fermentation Time } \\
(\mathbf{h})\end{array}$ \\
\hline 1 & 6.00 & 35.00 & 4.00 & 120.00 \\
\hline 2 & 8.00 & 45.00 & 2.50 & 72.00 \\
\hline 3 & 8.00 & 45.00 & 3.25 & 72.00 \\
\hline 4 & 8.00 & 45.00 & 2.50 & 72.00 \\
\hline 5 & 6.00 & 35.00 & 1.00 & 24.00 \\
\hline 6 & 8.00 & 45.00 & 2.50 & 72.00 \\
\hline 7 & 7.00 & 45.00 & 2.50 & 72.00 \\
\hline 8 & 10.00 & 55.00 & 4.00 & 24.00 \\
\hline 9 & 6.00 & 55.00 & 1.00 & 120.00 \\
\hline 10 & 8.00 & 45.00 & 2.50 & 72.00 \\
\hline 11 & 8.00 & 45.00 & 2.50 & 72.00 \\
\hline 12 & 8.00 & 50.00 & 2.50 & 72.00 \\
\hline 13 & 10.00 & 35.00 & 4.00 & 24.00 \\
\hline 14 & 8.00 & 45.00 & 1.75 & 72.00 \\
\hline 15 & 10.00 & 55.00 & 1.00 & 24.00 \\
\hline 16 & 8.00 & 45.00 & 2.50 & 48.00 \\
\hline 17 & 10.00 & 35.00 & 1.00 & 24.00 \\
\hline 18 & 10.00 & 35.00 & 4.00 & 120.00 \\
\hline 19 & 9.00 & 45.00 & 2.50 & 72.00 \\
\hline 20 & 10.00 & 55.00 & 1.00 & 120.00 \\
\hline 21 & 8.00 & 40.00 & 2.50 & 72.00 \\
\hline 22 & 6.00 & 35.00 & 4.00 & 24.00 \\
\hline 23 & 6.00 & 55.00 & 1.00 & 24.00 \\
\hline 24 & 10.00 & 55.00 & 4.00 & 120.00 \\
\hline 25 & 8.00 & 45.00 & 2.50 & 96.00 \\
\hline 26 & 6.00 & 35.00 & 1.00 & 120.00 \\
\hline 27 & 6.00 & 55.00 & 4.00 & 120.00 \\
\hline 28 & 8.00 & 45.00 & 2.50 & 72.00 \\
\hline 29 & 10.00 & 35.00 & 1.00 & 120.00 \\
\hline 30 & 6.00 & 55.00 & 4.00 & 24.00 \\
\hline & & & \\
\hline & & & \\
\hline
\end{tabular}

Table 2: RSM optimization design under CCD for the production of protease by BS-90 UV treated mutants of Bacillus subtilis. obtained during the research investigations have been described and discussed under the following sub-headings.

\section{UV Induced mutagenesis of Bacillus subtilis IBL-04}

Homogeneous cell suspension of Bacillus subtilis were used to treat the bacterial spores in UV irradiation mutagenesis for different time periods (30-120 min) with intervals of $30 \mathrm{~min}$. After UV irradiation, 100 fold serial dilution of mutated spores were plated to give 30 colonies or less per petri plate. UV irradiation was carried out in a semi dark room to increase the protease activity of Bacillus subtilis. The frequency of positive mutation and no of variable colonies increased by increasing the time of irradiation up to a limit. After that no of colonies decreased by increasing time period. The colonies which were showed more clear zones were selected as mutants for hyper production of protease [15]. Bacterial culture exposed to UV radiations for 90 min (UV-90) gave most prominent and relatively bigger size colonies (Figure 1).

\section{Colony restriction}

Triton X-100 is non-ionic detergent that generally has applications in laboratories. It has lipophobic polyethylene oxide chain and a hydrophobic group consisting of aromatic hydrocarbons chain. It is an efficient colony restrictor which causes to make the good, round, small sized and intense colonies.

\section{Isolation of mutants using skim milk as metabolic inhibitor}

The production of protease by Bacillus subtilis IBL-04 mutants was carried out in skim milk ( $1 \% \mathrm{w} / \mathrm{v})$ growth medium. Native strain of bacterium was incapable to proliferate in its presence i.e. parent bacterium growth was inhibited. Different UV treated mutants of Bacillus subtilis appearing on agar-plates using $1 \%$ skim milk have been show in Figure 2.

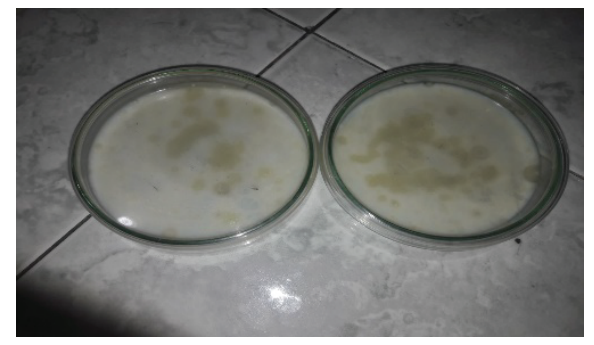

A: 30 min

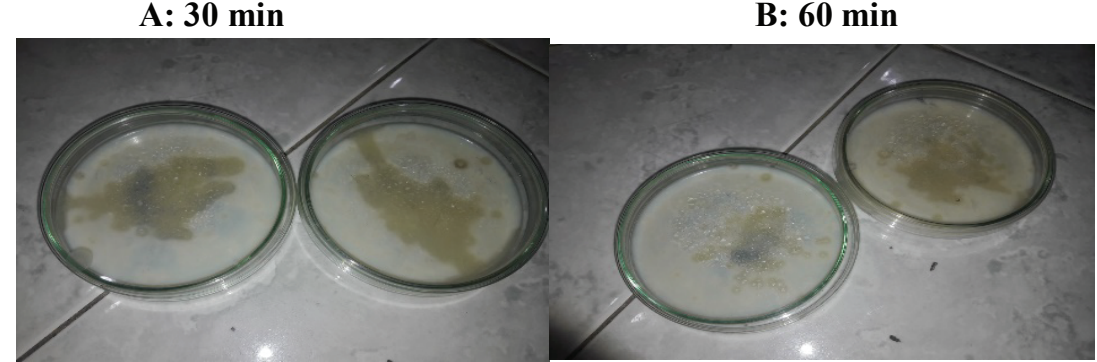

C: 90 min

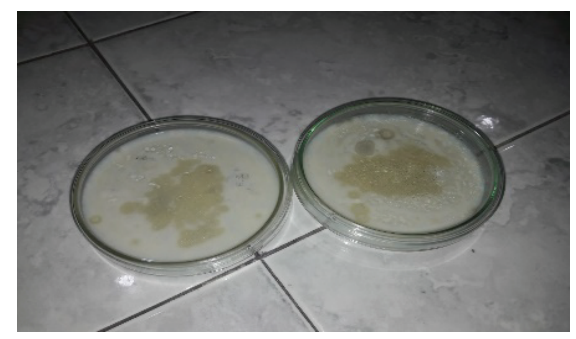

B: $60 \mathrm{~min}$

D: 120 min

Figure 1: Growth pattern of UV irradiation mutants of Bacillus subtilis treated for different periods. 

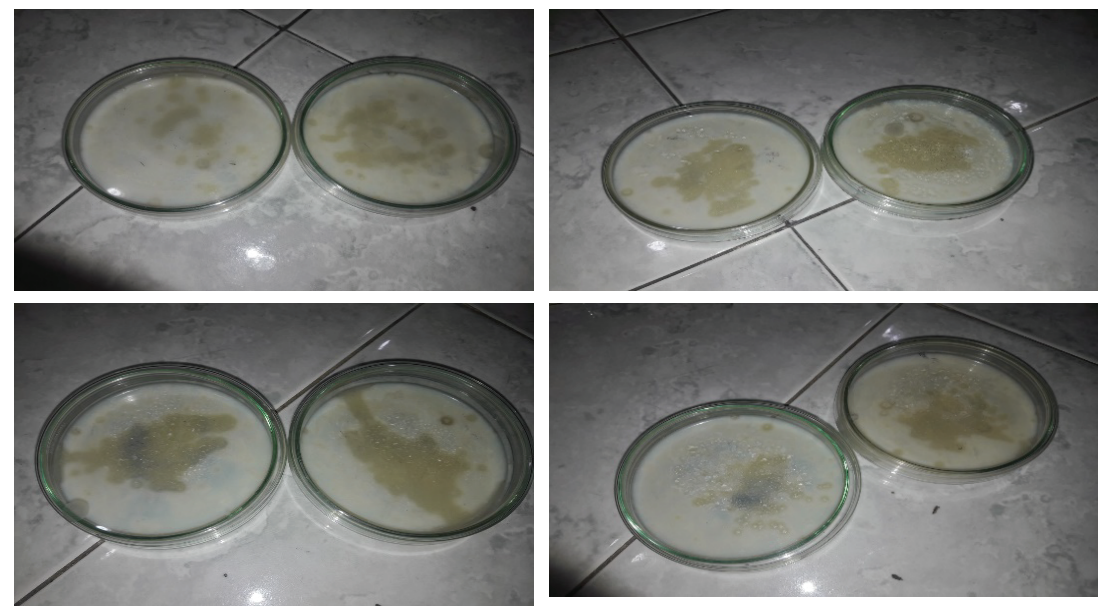

Figure 2: Selection of mutants treated with UV mutagenesis containing skim milk.

A researcher has previously reported the use of skim milk to isolate and select the protease producing mutants [17]. Elevated concentration $(1.5 \%)$ of skim milk for the isolation of mutants, plated on gelatine containing agar medium have been used and mutants have been screened on the basis of clearance zone shown on the medium. The sequential exposure to UV or Chemical mutagenic agents and the mutant selection with skim milk on the basis of growth restriction has also been reported. After screening it was found that mutated colonies were skim milk resistant.

\section{Protease production by selected mutants}

All the UV treated mutants and parent Bacillus subtilis IBL-04 were cultured in LSF for protease enzyme production using casein as substrate. It was observed that all the mutant strains produced higher enzyme activity as compared to parent strain (Table 3). However, the mutant treated for $90 \mathrm{~min}$ was the best protease producer $(90 \mathrm{IU} / \mathrm{mL})$.

Physical parameters optimization for enhanced production of UV-90 mutant protease by Bacillus subtilis using RSM

Using RSM in liquid substrate fermentation medium (LSF), independent variables were Inoculum size (A), Fermentation Time (B), $\mathrm{pH}(\mathrm{C})$ and Temperature (D) and interactive effects of these variables were investigated on the production of protease by Bacillus subtilis-90 mutant using casein as substrate. Four levels of each variable were studies in triplicates. In this study, four different factors were studied in a 30 runs design. The responses (Protease activity) were measured after carrying the experiments. Response values attained are the mean of triplicate trials. The optimal protease activities were observed at inoculum size, $2.50 \mathrm{~mL}$; fermentation time, $72 \mathrm{~h} ; \mathrm{pH}, 8$ and temperature $50^{\circ} \mathrm{C}$ (Table 4$)$.

The optimal operational conditions were found to enhance the mutant protease enzyme production. The single response variable was treated under Central Composite Design (CCD). A pragmatic model having the independent variables effect was developed employing the software to characterize the response surface. The maximum protease activity obtained was $95.89 \mathrm{IU} / \mathrm{mL}$ while minimum was $53.78 \mathrm{IU} / \mathrm{mL}$ using the same substrate.

For the dependent variable (protease production) or response (Y) a second order polynomial equation was used in terms of linear, cross product and quadratic equations. Statistical calculation was implicit

\begin{tabular}{|c|c|c|}
\hline Sr. No. & Exposure Time (min) & Enzyme Activity (U/mL) \\
\hline 1 & 0 & 79 \\
\hline 2 & 30 & 62 \\
\hline 3 & 60 & 85 \\
\hline 4 & 90 & 90 \\
\hline 5 & 120 & 69 \\
\hline
\end{tabular}

Table 3: Effect of UV light exposure on protease enzyme production by Bacillus subtilis mutants.

\begin{tabular}{|c|c|c|c|c|c|}
\hline Run & $\mathbf{p H}$ & $\begin{array}{c}\text { Temperature } \\
\left({ }^{\circ} \mathbf{C}\right)\end{array}$ & $\begin{array}{c}\text { Inoculum Size } \\
(\mathbf{m L})\end{array}$ & $\begin{array}{c}\text { Fermentation } \\
\text { Time }(\mathbf{h})\end{array}$ & $\begin{array}{c}\text { Protease (IU/ } \\
\mathbf{m L})\end{array}$ \\
\hline 1 & 6.00 & 35.00 & 4.00 & 120.00 & 67.7 \\
\hline 2 & 8.00 & 45.00 & 2.50 & 72.00 & 90.89 \\
\hline 3 & 8.00 & 45.00 & 3.25 & 72.00 & 87.54 \\
\hline 4 & 8.00 & 45.00 & 2.50 & 72.00 & 91.3 \\
\hline 5 & 6.00 & 35.00 & 1.00 & 24.00 & 78.6 \\
\hline 6 & 8.00 & 45.00 & 2.50 & 72.00 & 87.67 \\
\hline 7 & 7.00 & 45.00 & 2.50 & 72.00 & 88.9 \\
\hline 8 & 10.00 & 55.00 & 4.00 & 24.00 & 58.9 \\
\hline 9 & 6.00 & 55.00 & 1.00 & 120.00 & 66.45 \\
\hline 10 & 8.00 & 45.00 & 2.50 & 72.00 & 92.78 \\
\hline 11 & 8.00 & 45.00 & 2.50 & 72.00 & 93.5 \\
\hline 12 & 8.00 & 50.00 & 2.50 & 72.00 & 95.89 \\
\hline 13 & 10.00 & 35.00 & 4.00 & 24.00 & 62.45 \\
\hline 14 & 8.00 & 45.00 & 1.75 & 72.00 & 93.9 \\
\hline 15 & 10.00 & 55.00 & 1.00 & 24.00 & 64.57 \\
\hline 16 & 8.00 & 45.00 & 2.50 & 48.00 & 91.2 \\
\hline 17 & 10.00 & 35.00 & 1.00 & 24.00 & 58.9 \\
\hline 18 & 10.00 & 35.00 & 4.00 & 120.00 & 53.78 \\
\hline 19 & 9.00 & 45.00 & 2.50 & 72.00 & 82.36 \\
\hline 20 & 10.00 & 55.00 & 1.00 & 120.00 & 60.3 \\
\hline 21 & 8.00 & 40.00 & 2.50 & 72.00 & 92.45 \\
\hline 22 & 6.00 & 35.00 & 4.00 & 24.00 & 72.67 \\
\hline 23 & 6.00 & 55.00 & 1.00 & 24.00 & 69.9 \\
\hline 24 & 10.00 & 55.00 & 4.00 & 120.00 & 55.46 \\
\hline 25 & 8.00 & 45.00 & 2.50 & 96.00 & 93.01 \\
\hline 26 & 6.00 & 35.00 & 1.00 & 120.00 & 73.45 \\
\hline 27 & 6.00 & 55.00 & 4.00 & 120.00 & 63.45 \\
\hline 28 & 8.00 & 45.00 & 2.50 & 72.00 & 90.45 \\
\hline 29 & 10.00 & 35.00 & 1.00 & 120.00 & 59.87 \\
\hline 30 & 6.00 & 55.00 & 4.00 & 24.00 & 71.34 \\
\hline & & & & & \\
\hline
\end{tabular}

Table 4: Protease activity response by RSM under CCD for optimization of physical parameters. 
to the coded independent variables according to the Eq. 1 mentioned below:

$$
X_{i}=\left(x_{i}-x_{o}\right) / x_{i}
$$

Here $\mathrm{X}_{\mathrm{i}}$ is the non-dimensioned coded value of independent variables, $x_{i}$ is the actual value of that independent variable, $x_{0}$ is the real value of that independent variable $\mathrm{x}_{\mathrm{i}}$ at the central point, $\Delta \mathrm{x}_{\mathrm{i}}$ is the step change value. The action of every variabl, their interactions and statistical examination to acquire the predicted yields is illustrated by using the quadratic Eq. 2 mentioned below:

$$
Y=\beta_{o}+\Sigma \beta_{i} X_{i}+\Sigma \beta_{i j} X_{i} X_{j}+\Sigma \beta_{i i} X_{i}^{2}+e
$$

In this equation $\mathrm{Y}$ is the predicted response, $\mathrm{X}_{\mathrm{i}} \mathrm{X}_{\mathrm{j}}$ are levels of independent variables of linear, quadratic coefficients and $e$ is the random error [18].

\section{ANOVA for the response (protease) surface model}

The observed response values variability comparison with the experimental variables and their interaction was calculated by the coefficient of determination $\left(\mathrm{R}^{2}\right)$. The goodness of model fitting was measured by $\mathrm{R}^{2}$. Its value ranges $0-1$ while near to 1 may predict to be a good fitted model [6]. The calculated coefficient of determination for protease production was 0.9842 that could elucidate up to $98.42 \%$ response variability. That was comparable to $\mathrm{R}^{2}$ value of 0.9842 [19]. The mathematical response model is considered to be reliable with an $\mathrm{R}^{2}$ value of 0.9842 . The adjusted $\mathrm{R}^{2}$ value was 0.9695 suggesting a significant model by determining the close relationship to the actual $\mathrm{R}^{2}$ value. Predicted $\mathrm{R}^{2}$ value shown in this model was 0.9133 . The "Pred R-Squared" of 0.9133 is close as to the "Adj R-Squared" of 0.9695 as expected (Table 5).

Adequate Precision was used to measure the signal to noise ratio. A ratio larger than 4 is advantageous. Here, the ratio of 22.60 attained in this model represents an adequate signal. It recommends the model was capable to explicate $22.60 \%$ of the overall variations. The reliability of the experimental values can be dealt by measuring the coefficient of the variation (C.V). High degree of precision is collaborated with the small value of (C.V). In the present case C.V calculated was 3.25 which indicates the good level of model precision and reliability (Table 6).

The results of analysis of variance (ANOVA) are shown in the Table 6. The F test and subsequent $\mathrm{P}$ values with the factors were predicted. The lesser the $\mathrm{P}$ value, the greater is the importance of corresponding coefficient [20]. Whereas model indicates that the F-value was 66.78 . The Quadratic Model has F-value of 66.78 which indicates that the model is significant. Approximately $0.01 \%$ chance that the "Model F-Value" could occur due to noise. There is another way which indicates that the model terms are significant if the Values of "Prob $>F$ " are less than 0.0500 .

Here some model terms are significant like A, C, D, $\mathrm{A}^{2}$ and $\mathrm{AB}$. If the values are greater than 0.1000 so it shows that the model terms are non-significant.If there are many non-significant model terms so the model reduction may improve your model. The "Lack of Fit F-value"

\begin{tabular}{|c|c|c|c|}
\hline Model Terms & Value & Model Terms & Value \\
\hline Std. Dev. & 2.50 & R-Squared & 0.9842 \\
\hline Mean & 76.99 & Adj R-Squared & 0.9695 \\
\hline C.V. & 3.25 & Pred R-Squared & 0.9133 \\
\hline PRESS & 514.13 & Adeq Precision & 22.604 \\
\hline
\end{tabular}

Table 5: ANOVA values for mutant protease hyper production response surface

\begin{tabular}{|c|c|c|c|c|c|c|}
\hline Source & $\begin{array}{l}\text { Sum of } \\
\text { Squares }\end{array}$ & DF & $\begin{array}{l}\text { Mean } \\
\text { Square }\end{array}$ & F-Value & $\begin{array}{l}\text { P-Value } \\
\text { Prob }>F\end{array}$ & \\
\hline Model & 5834.986 & 14 & 416.7847 & 66.77557 & $<0.0001$ & Significant \\
\hline $\mathrm{A}: \mathrm{pH}$ & 519.6824 & 1 & 519.6824 & 83.26143 & $<0.0001$ & \\
\hline B: Temperature & 14.24296 & 1 & 14.24296 & 2.28195 & 0.1517 & \\
\hline C: Inoculum Size & 52.63521 & 1 & 52.63521 & 8.433002 & 0.0109 & \\
\hline $\begin{array}{l}\text { D: Fermentation } \\
\text { Time }\end{array}$ & 78.3928 & 1 & 78.3928 & 12.55978 & 0.0029 & \\
\hline$A^{2}$ & 119.8132 & 1 & 119.8132 & 19.19598 & 0.0005 & \\
\hline $\mathrm{B}^{2}$ & 8.936584 & 1 & 8.936584 & 1.431784 & 0.2500 & \\
\hline $\mathrm{C}^{2}$ & 6.970661 & 1 & 6.970661 & 1.116811 & 0.3073 & \\
\hline $\mathrm{D}^{2}$ & 0.14455 & 1 & 0.14455 & 0.023159 & 0.8811 & \\
\hline$A B$ & 40.67251 & 1 & 40.67251 & 6.516386 & 0.0221 & \\
\hline$A C$ & 0.002256 & 1 & 0.002256 & 0.000361 & 0.9851 & \\
\hline$A D$ & 2.287656 & 1 & 2.287656 & 0.366519 & 0.5540 & \\
\hline$B C$ & 0.288906 & 1 & 0.288906 & 0.046287 & 0.8326 & \\
\hline $\mathrm{BD}$ & 0.094556 & 1 & 0.094556 & 0.015149 & 0.9037 & \\
\hline$C D$ & 10.67656 & 1 & 10.67656 & 1.710555 & 0.2106 & \\
\hline Residual & 93.62361 & 15 & 6.241574 & & & \\
\hline Lack of Fit & 72.76973 & 10 & 7.276973 & 1.744753 & 0.2801 & $\begin{array}{c}\text { Non- } \\
\text { significant }\end{array}$ \\
\hline Pure Error & 20.85388 & 5 & 4.170777 & & & \\
\hline Cor Total & 5928.61 & 29 & & & & \\
\hline
\end{tabular}
model.
Table 6: ANOVA for response surface quadratic model.

is non-significant which is 1.74 . It is extremely near to the pure error. Only $28.01 \%$ chance that the "Lack of Fit F-value" could occur due to noise. Non-significant lack of fit is good - we want the model to fit.

\section{Regression coefficient for protease enzyme production from Bacillus subtilis}

In case of regression coefficient model, the positive and negative coefficient of any factor indicates that it has significant effect on protease enzyme production. The positive values of linear coefficient indicates that production of protease enzyme increased with initial increase in any factor. While the negative linear coefficient for $\mathrm{pH}$, temperature, inoculum size and fermentation time indicated that at higher levels of these factors protease activity decreased.

The $t$ and $p$ values are usually applied to analyze the significance of each coefficient. Greater $t$ test value and lower the $p$ value depicts greater significance of corresponding coefficient. $\mathrm{P}$ value $\mathrm{P} \leq 0.01$ predicts that model terms are highly significant (Table 7).

\section{Interactions between varying variables}

The response surface graphs are displayed to elucidate the relations of the different variables and to search the optimum point of all variables to attain a maximum yield. The (3D) plots are usually plotted to explain the interaction between different physicochemical parameters and to find optimal value of each variablefor optimal protease production . The curves were generated by plotting response (Protease production) on the Z-axis opposite to two independent factors whereas maintaining the other independent (factors) variables at their O-level.

Inoculum size vs. fermentation time: The 3D Response Surface Plots showed the highest protease activity $86.7786 \mathrm{IU} / \mathrm{mL}$ produced by Bacillus subtilis when $\mathrm{pH}$ 6-10 was maximum and temperature ranged from $35-55^{\circ} \mathrm{C}$. The interaction between $\mathrm{pH}$ and temperature was not significant (Figure 3).

pH vs. temperature: The $3 \mathrm{D}$ response surface plots showed the highest protease activity $93.6375 \mathrm{IU} / \mathrm{mL}$ produced by Bacillus subtilis 
Citation: Mohsin I, Muhammad A, Fareeha B (2017) Development of Bacillus subtilis Mutants for Overproduction of Protease. J Microb Biochem Technol 9:174-180. doi: 10.4172/1948-5948.1000363

\begin{tabular}{|l|c|c|c|c|}
\hline \multicolumn{1}{|c|}{ Term } & Coefficient & SE Coefficient & $\mathbf{T}$ & $\mathbf{P}$ \\
\hline Intercept & 91.79 & 0.69 & 133.02 & 0.0001 \\
\hline A:pH & -5.61 & 0.62 & -9.04 & 0.0001 \\
\hline B:Temperature & -0.93 & 0.62 & -1.5 & 0.1517 \\
\hline C:Inoculum Size & -1.79 & 0.62 & -2.88 & 0.0109 \\
\hline D:Fermentation Time & -2.18 & 0.62 & -3.51 & 0.0029 \\
\hline A & -26.83 & 6.12 & -4.38 & 0.0005 \\
\hline B & 7.33 & 6.12 & 1.19 & 0.2500 \\
\hline C & -6.47 & 6.12 & -1.05 & 0.3073 \\
\hline D & -0.93 & 6.12 & -0.15 & 0.8811 \\
\hline AB & 1.59 & 0.62 & 2.56 & 0.0221 \\
\hline AC & 0.012 & 0.62 & 0.01 & 0.9851 \\
\hline AD & 0.38 & 0.62 & 0.61 & 0.5540 \\
\hline BC & 0.13 & 0.62 & 0.20 & 0.8326 \\
\hline BD & -0.077 & 0.62 & -0.12 & 0.9037 \\
\hline CD & -0.82 & 0.62 & -1.32 & 0.2106 \\
\hline
\end{tabular}

Table 7: Estimated regression coefficients for protease production by Bacillus subtilis in LSF.

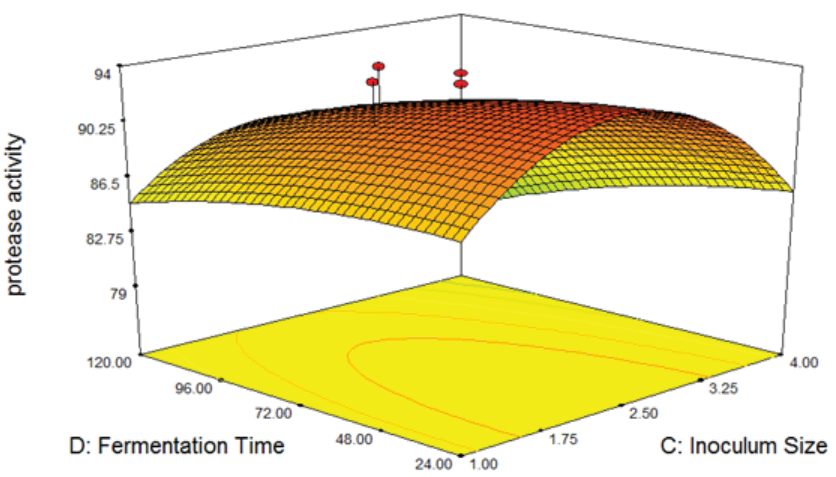

Figure 3: Response surface showing interaction effects of inoculum size vs. fermentation time as protease parameter.

when $\mathrm{pH}$ 6-10 was maximum and temperature ranged from $35-55^{\circ} \mathrm{C}$. The interaction between $\mathrm{pH}$ and temperature was significant (Figure 4).

Inoculum size vs. pH: The 3D Response Surface Plots showed the highest protease activity $86.7786 \mathrm{IU} / \mathrm{mL}$ produced by Bacillus subtilis when $\mathrm{pH}$ 6-10 was maximum and temperature ranged from $35-55^{\circ} \mathrm{C}$. The interaction between $\mathrm{pH}$ and inoculum size was not significant (Figure 5).

Fermentation time vs. pH: The 3D Response Surface Plots showed the highest protease activity $86.7786 \mathrm{IU} / \mathrm{mL}$ produced by Bacillus subtilis when $\mathrm{pH}$ 6-10 was maximum and temperature ranged from $35-55^{\circ} \mathrm{C}$. The interaction between $\mathrm{pH}$ and fermentation time was not significant (Figure 6).

Inoculum size vs. temperature: The 3D Response Surface Plots showed the highest protease activity $93.6375 \mathrm{IU} / \mathrm{mL}$ produced by Bacillus subtilis when $\mathrm{pH}$ 6-10 was maximum and temperature ranged from $35-55^{\circ} \mathrm{C}$. The interaction between inoculum size and temperature was not significant (Figure 7).

Fermentation time vs. temperature: The 3D response surface plots showed the highest protease activity $93.6375 \mathrm{IU} / \mathrm{mL}$ produced by Bacillus subtilis when $\mathrm{pH}$ 6-10 was maximum and temperature ranged from $35-55^{\circ} \mathrm{C}$. The interaction between fermentation time and temperature was not significant (Figure 8).

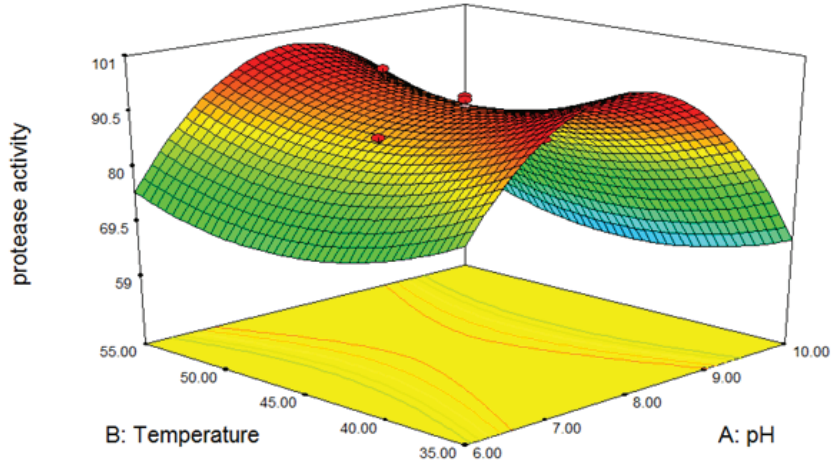

Figure 4: Response surface showing interaction between $\mathrm{pH}$ and temperature on protease yield (hold value: inoculum size, $2.50 \mathrm{~mL}$; fermentation time $72 \mathrm{~h}$ ).

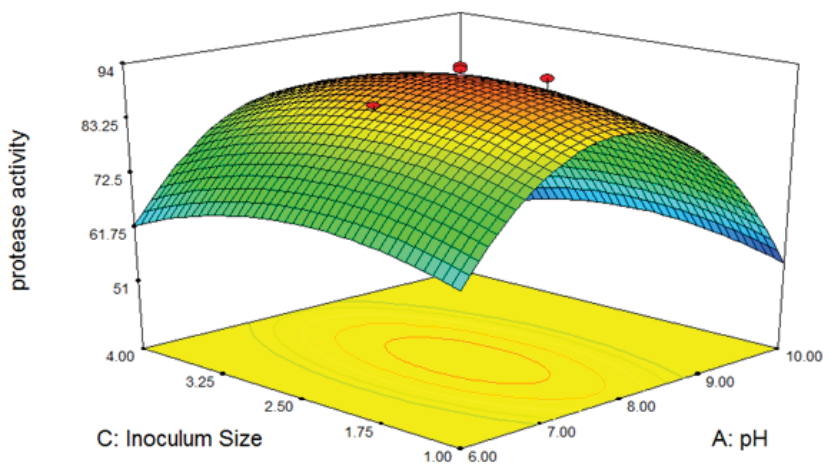

Figure 5: Response surface showing interaction between $\mathrm{pH}$ and temperature $\left(45^{\circ} \mathrm{C}\right)$ on protease yield (hold value: fermentation time $72 \mathrm{~h}$ ).

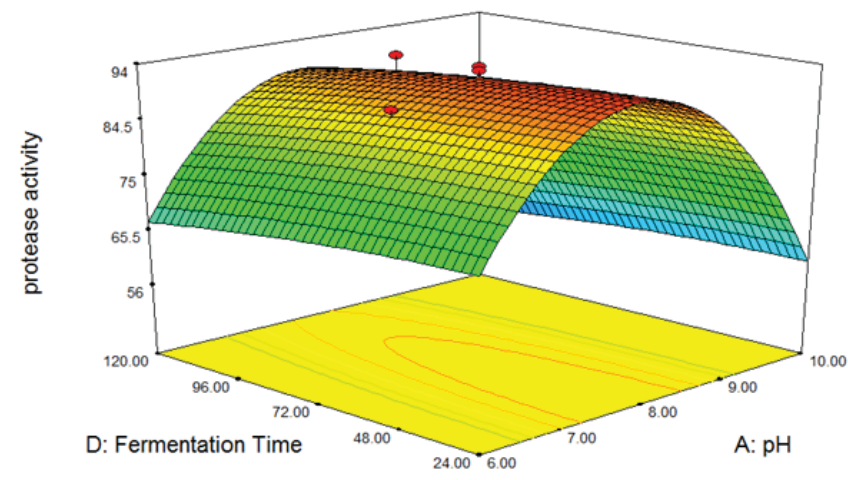

Figure 6: Response surface showing interaction between $\mathrm{pH}$ and temperature $\left(45^{\circ} \mathrm{C}\right)$ on protease yield (hold value: inoculum size, $2.50 \mathrm{~mL}$ ).

It was reported that the constant and highest protease enzyme activity was observed at $\mathrm{pH}$ between $6-10^{\circ} \mathrm{C}$. The optimum $\mathrm{pH}$ for alkaline protease was observed at $8^{\circ} \mathrm{C}$. The production at $\mathrm{pH} 7$ and 8 are mostly comparable [21]. The maximum enzyme activity was 95.89 $(\mathrm{IU} / \mathrm{mL})$ at optimum $\mathrm{pH}$ 8. It means $\mathrm{pH} 8$ is more favorable for protease production. It was also observed that if inoculum size was reduced $(0.2 \%)$ so it may cause less protease enzyme production. Pseudomonas sp. has been reported that $1.5 \%$ inoculum showed maximum enzyme production Similarly Bacillus subtilis has $2.5 \%$ inoculum size which showed maximum enzyme production. It is relatively comparable. Halobacterium sp. has been reported that maximum protease 
Citation: Mohsin I, Muhammad A, Fareeha B (2017) Development of Bacillus subtilis Mutants for Overproduction of Protease. J Microb Biochem Technol 9:174-180. doi: 10.4172/1948-5948.1000363

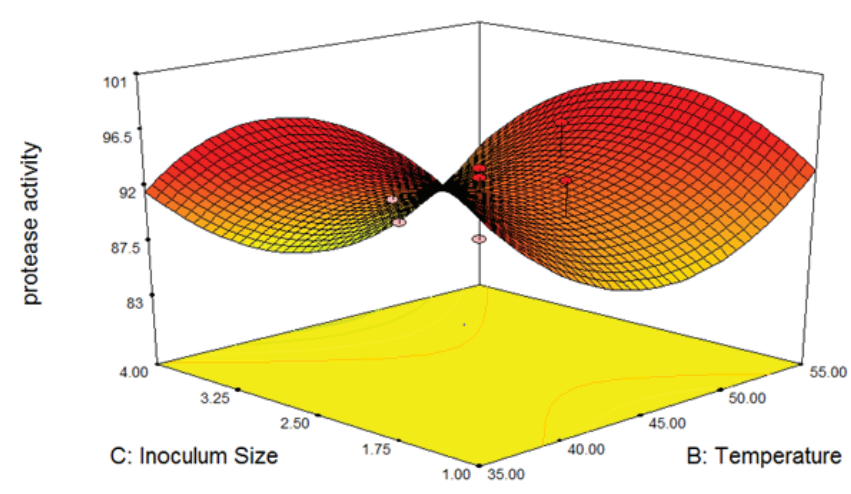

Figure 7: Response surface showing interaction between $\mathrm{pH}(8)$ and temperature on protease yield (hold value: fermentation time $72 \mathrm{~h}$ ).

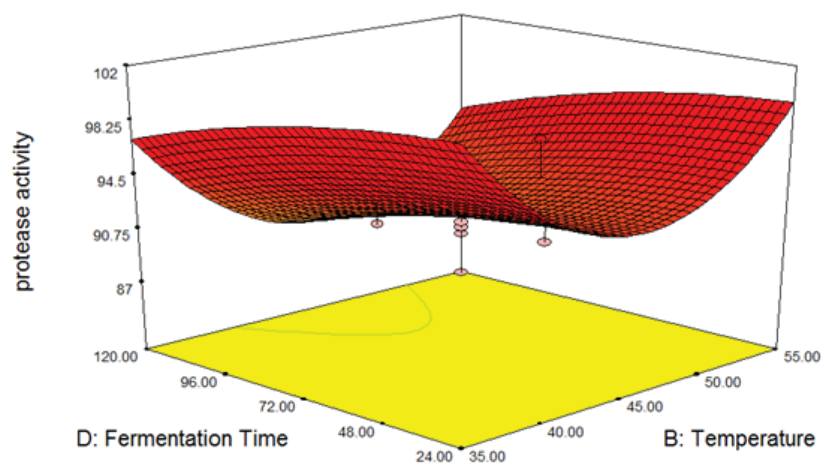

Figure 8: Response surface showing interaction between $\mathrm{pH}(8)$ and temperature on protease yield (hold value: inoculum size, $2.50 \mathrm{~mL}$ ).

production was achieved $96 \mathrm{~h}$ incubation period. The Bacillus subtilis gave maximum protease production in $72 \mathrm{~h}$ incubation time.

\section{Conclusion}

The results obtained confirmed that UV-mutagenesis technique is an important tool in Bacillus improvement for increasing production of alkaline protease enzyme. The selected hyper producing Bacillus mutant may have the potential in biotechnological applications.

\section{References}

1. Balachandran C, Duraipandiyan V, Ignacimuthu S (2012) Purification and characterization of protease enzyme from actinomycetes and its cytotoxic effect on cancer cell line (A549). Asian Pac J Trop Biomed 2: 392-400.

2. Amara AA, Salem SR, Shabeb MSA (2009) The possibility to use bacterial protease and lipase as biodetergent. Glob J Biotech Biochem 4: 104-114.

3. Ward OP (2009) Advances in applied bioremediation, pp: 1-19.

4. Uddin ME, Rahman M, Faruquee HM, Khan MRI, Ahammed T, et al. (2015) Identification, partial purification and characterization of protease enzyme from locally isolated soil bacterium. Amer Res J Bio Sci 1: 2379-7959.

5. Kumar R, Vats R (2010) Protease production by Bacillus subtilis immobilized on different matrices. J N Y Sci 3: 20-24.

6. Pant G, Prakash A, Pavani JVP, Bera S, Deviram GVNS, et al. (2015) Production, optimization and partial purification of protease from Bacillus subtilis. J Taibah Univ Sci 9: 50-55.
7. Chu IM, Lee C, Li TS (1992) Production and degradation of alkaline protease in batch cultures of Bacillus subtilis ATCC 14416. Enzyme Microb Technol 14:755-761.

8. Bhunia B, Basak B, Dey A (2012) A review on production of serine alkaline protease by Bacillus spp. J BiochemTech 3: 448-457.

9. Cox EC, Degnen GE, Scheppe ML (1972) Mutator gene studies in Escherichia coli: The Muts gene. Genetics 72: 551-567.

10. Priest FG (1977) Extracellular enzyme synthesis in the genus Bacillus. Bacteriol Rev 41:711-753.

11. Zenoff VF, Sineriz F, Farías ME (2006) Diverse responses to UV-B radiation and repair mechanisms of bacteria isolated from high-altitude aquatic environments. Appl Environ Microbiol 72: 7857-7863.

12. Wolf DH, Hilt W (2004) The proteasome: A proteolytic nanomachine of cell regulation and waste disposal. Biochim Biophys Acta 1695: 19-31.

13. Sher MG, Nadeem M, Syed Q, Irfan M, Baig S (2012) Protease production from UV mutated Bacillus subtilis. Bangladesh J Sci Indust Res 47: 69-76.

14. Naidu KS (2011) Characterization and purification of protease enzyme. J App Pharm Sci 1: 107-112.

15. Mrudula S, Begum AA, Ashwitha K, Pindi PK (2012) Enhanced production of alkaline protease by Bacillus subtilis in submerged fermentation. Int J Pharm Bio Sci 3: 619 - 631

16. Geethanjali S, Subash A (2011) Optimization of protease production by Bacillus subtilis isolated from mid gut of fresh water fish Labeo rohita. World J Fish Mar Sci 3: 88-95.

17. Alnahdi HS (2012) Isolation and screening of extracellular proteases produced by new isolated Bacillus sp. J App Pharm Sci 2: 71.

18. Mushtaq Z, Adnan A, Mehmood Z, Syed Q (2014) Process optimization by response surface methodology for extracellular alkaline protease production from Bacillus subtilis. Pak J Bot 46: 699-704.

19. Racheal OO, Ahmed ATF, Ndigwe EV, Morakinyo SD (2015) Extraction, purification and characterization of protease from Aspergillus niger isolated from yam peels. Inter J Nut Food Sci 4: 125-131.

20. Omidinia $E$ (2012) Isolation, purification and characterization of a thermophilic alkaline protease from Bacillus subtilis BP-36. J Sci 23: 7-13.

21. Arunkumar T, Anand A, Narendrakumar G (2014) Application of response surface methodology (RSM)-CCD for the production of laccases using submerged fermentation. Intern J Pharma Bio Sci 5: 429-438. 